\title{
Technogenic Mercury Environment Pollution and Human Health in Mining Settlement of FEFD
}

\author{
L. T. Krupskaya ${ }^{1,2}$, K.E. Gula ${ }^{1,}$ \\ ${ }^{1}$ Pacific National University, 136, Tikhookeanskaya str, \\ Khabarovsk, 680035, Russian Federation \\ ${ }^{2}$ Far East Scientific-Research Institute of Forestry, 71, \\ Volochaevskaya str, Khabarovsk, 680020 Russian \\ Federation
}

\author{
N.G. Volobueva \\ Northeastern State University, 13, Portovaya st, Magadan, \\ 685000, Russian Federation
}

\begin{abstract}
The article deals with the problems of technogenic mercury pollution of environment and population health effects in the mining settlement in the Far Eastern Federal District (FEFD). The measures are proposed to reduce its harmful impact.
\end{abstract}

Keywords-technogenic, mercury pollution, objects, environment, negative impact, health of population

\section{INTRODUCTION}

In the Far Eastern Federal District of Russia, large areas are contaminated with mercury owing to development of precious metals placer deposits in the last century. Till 1990 s gold was recovered from the rough gravity concentrates by amalgamation, that is, gold was extracted from concentrates using mercury wetting. As a result the extensive mercury contamination of the environment in river valleys occurred, which is confirmed by our geoecological research. Mercury can accumulate not only in the biosphere components, but also in the animal, bird, fish and human organism, negatively effecting them. Therefore, the aim of the study was to assess the anthropogenic impact on the environment and human health. Proceeding from the aim, the following tasks have been formulated: 1 . To review and synthesize the literature on this problem; 2. To assess the impact of mercury pollution on environment habitat and human health; 3 . To propose the measures to reduce the negative mercury impact on the environment and the population of a mining settlement.

\section{OBJECTS AND METHODS OF RESEARCH}

The objects of the study were waste of the placer goldconcentrating plant/unit, soils, plants, water, human health.

Methodological basis of the research was the study of Academician V.I. Vernadsky about biosphere and noosphere [1] and the guidelines from the programme and methodology for technogenic biogeocenose studying by B.P. Kolesnikov and L.V. Motorina [2].

Pilot studies have been carried out since 1997 till 2013 at the territory of a mining company located under rugged environment of FEFD in Northern Sikhote-Alin.

\author{
V.P. Zvereva \\ Far East Federal University, 8, Sukhanova str, Vladivostok, \\ 690091, Russian Federation
}

Far East Geological Institute FEB RAS, 159, Prospect 100 let Vladivostoka, Vladivostok, 690022, Russian Federation

\section{V.T. Tagirova}

Far Eastern State University of Humanities, str. Karl Marx, 68, Khabarovsk, 680000, Russian Federation

The pattern of these problems decision led to the use of the following set of basic methods and techniques: scientific prediction, systematization and scientific classification. For the programme implementation the main and defining systemic-integrated approach was used, as it meets the nature of its original subject, as well as contemporary instrumental and traditional physical-chemical and chemical methods, simulation, statistical processing of the data.

For the study of movable toxic elements pollution of ecosystems the following methods of sample preparation were used: 1. Incomplete destruction of silicate base by mixtures of acids: nitric and hydrochloric acids (after preashing at $\left.450{ }^{\circ} \mathrm{C}\right) ; 2$. Full destruction of the silicate base by hydrofluoricand perchloric acids. In the solution after filtration copper, lead, zinc, cadmium and antimony were determined by atomic absorption with electrothermal atomization (atomic absorption spectrophotometer Z-9000, Hitachi Company, Japan). The results were compared using complexometric method for lead and zinc testing. Concentrating of mercury from industrial waste water was as follows: in the field a fresh industrial water sample of 0.5 -1.0 liter was filtered through ash-free paper filter "White Ribbon" into a conical flask. The first portions of the filtrate were infiltrated again. Then it together with suspension was placed in a bag made of tracing paper, made up to air dried state. Nitric acid was added to filtrate for preservation, it together with suspension was transported to the laboratory of the Institute. Immediately prior to the mercury determination a filter with sediment was placed in a flask with an air refrigerator, $7 \mathrm{ml}$ of concentrated nitric acid, $3 \mathrm{ml}$ of concentrated $\mathrm{HCLO}_{4}$ and $0.1 \mathrm{~g}$ of a solid $\left(\mathrm{NH}_{4}\right)$ $\mathrm{S}_{2} \mathrm{O}_{8}$ were added. All mixture was gently heating until the filter destruction, the perchloric acid fumes and bleaching solution appearing. Then the calibration curve was constructed.

The mercury solution obtained after concentration was transferred to a $50 \mathrm{ml}$ measuring flask, and the volume was made up with nitric acid (1: 1). The flask content was cooled by snow or ice. Before measuring a chilled solution was transferred in the reaction flask and $5 \mathrm{ml}$ of the mixture was added, it was prepared by dissolution of $125 \mu \mathrm{g} / \mathrm{ml}$ of 
$\mathrm{SnCl}_{2}$ in $\mathrm{HCl}(2: 1)$ and $25 \mathrm{~g}$ of $\mathrm{CdCl}_{2}$ in $60 \mathrm{ml}$ of $\mathrm{HCl}$ (2: 1). The flask was immediately connected to Drexel bottle, and the fluid was mixing by shaking. As soon as the selected mercury vapor came into the absorption cell, the circulation pump started. The absorption value has gradually reached the peak. A constant level of absorption was set up in the cell during 1 minute. The reaction vessel disconnected from the system, and mercury vapor was pumped out into the potassium permanganate solution. The method described above allows to determine mercury in waters ranging from the background values $(0.01-0.02 \mu \mathrm{g} / 1)$.

Bioindication assessment of environmental components was carried out by M.S. Gilyarov's methodology. Microbiocenosis structure was studied by D.G. Zvyagintsev method. For mining enterprises environment of the Russian Far East the authors used the method of express assessment of the biosphere components state using the test-systems "Pollen Sterility" and "Growth test" [3 ]. Plant pollen sterility was determined in the time preparations stained with iodine solution according to Gramm. Mathematical processing of the results was made using PC software packages, based on generally accepted variation statistics methods.

\section{IIIRESULTS AND DISCUSSION}

The available information on the problem of mercury technogenic pollution and its impact on the health of the population of mining settlement was analyzed [4-7 et al].

The authors made an analytical review of publications on the environment technogenic factors impact. The social legal basis of environmental protection and the formulation of the problem was studied. It was found that at present stage the migration regularities of toxic chemicals in the biosphere components in the waste zone of placer goldconcentrating plant influence, as well as their role in the formation of ecologically-caused diseases were not studied. The problems relevant for the area under study connected with an integrated assessment of the mercury contaminated waste impact on the environment and the population health have been poorly studied.

Under the conditions of the mining company under study the active deposits and mining waste are of a great hazard to biota. The length of the placer district is about 14 $\mathrm{km}$, with an average width of industrial outline being $225 \mathrm{~m}$ $(20-500 \mathrm{~m})$. The placer has been operated since 1888 . Technogenic mineral formations (waste) in the upper reaches of the river are presented as piles of hydraulic mining, and in the middle and lower reaches - as those of dredging. The wastes include also the placer goldconcentrating waste, which are stored in bulk storage within the territory of the settlement.

Mineralogical analysis of primary concentrates (Yatlukova N. G., 1994) has shown that the light fraction is represented by quartz and micaceous minerals. The bulk of the heavy fraction are magnetite, hematite, sulfides (pyrite, cinnabar, sometimes galena). Limonite on pyrite is widely common. Ilmenite, zircon, chromite, grossular, anatase are also met.

Semiquantitative spectral analysis showed that in some fractions of concentrate $\mathrm{Pb}$ content reaches $0.3-0.4 \%, \mathrm{Cu}$ $0.03 \%, \mathrm{Zn}-0.04-0.07 \%$ and $\mathrm{Sb}-0.03 \%$, As $-0.1 \%$.

For the assessment of dump complex wastes, the authors determined in them the mobile forms of certain chemical elements. Great amounts of toxic chemical elements such as: $\mathrm{Pb}, \mathrm{Cu}, \mathrm{As}$, were found. It was revealed that technogenic and natural (cinnabar) mercury contamination of waste is very high. As dumps and other wastes are practically not isolated from water systems, they undoubtedly have a negative impact on ecosystems in their area of their influence. On the the basis of waste composition and properties it was concluded that it is necessary urgently process clay-dredging waste (eifel) fraction and "black sand" (waste, including wastes of placer gold-concentrating unit), for the purpose of technogenic mercury and other toxic substances extraction. The level of technogenic pollution of ecosystems with mineral materials processing waste was studied. When comparing the concentrations of heavy metals (HM) in the dissolved phase of snow cover the excess of MPC values was found: $\mathrm{Cu}$ - by $12, \mathrm{Hg}$-by 4 , Mn-by 3.5, Zn-by 2 times. A large areal pollution was revealed, especially in soils, its upper horizons $\left(\mathrm{A}_{0}\right.$ and $\left.\mathrm{A}_{1}\right)$, as well as in vegetation and bed deposits. Migration regularities of HM in system were found: waste $\rightarrow$ snow cover $\rightarrow$ soils $\rightarrow$ vegetation $\rightarrow$ human being. The bioindication method made it possible to assess the ecological state of the environment objects of the study area as unsatisfactory and catastrophic. The unfavorable ecological situation causes the growth of population morbidity (fig. 1,2). A relationship between habitat quality and morbidity growth (especially for children) was revealed. HM content in biological material (hair) turned out to be higher by 1.4 and more times compared to other Russian regions (table 1).

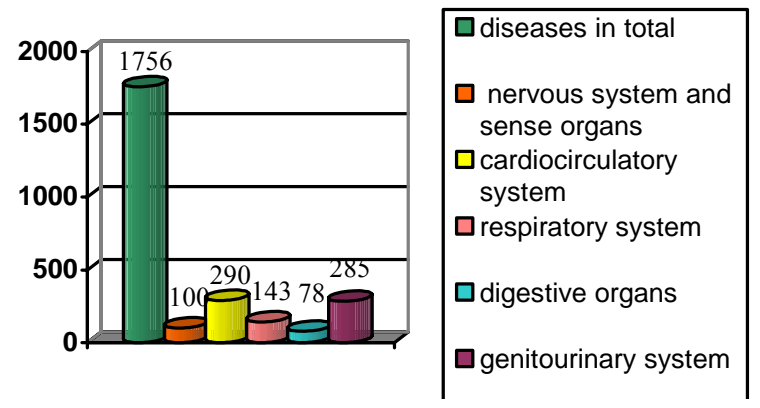

Figure 1. - Average values of morbidity of Briakan settlement population in $1997-2012$ 


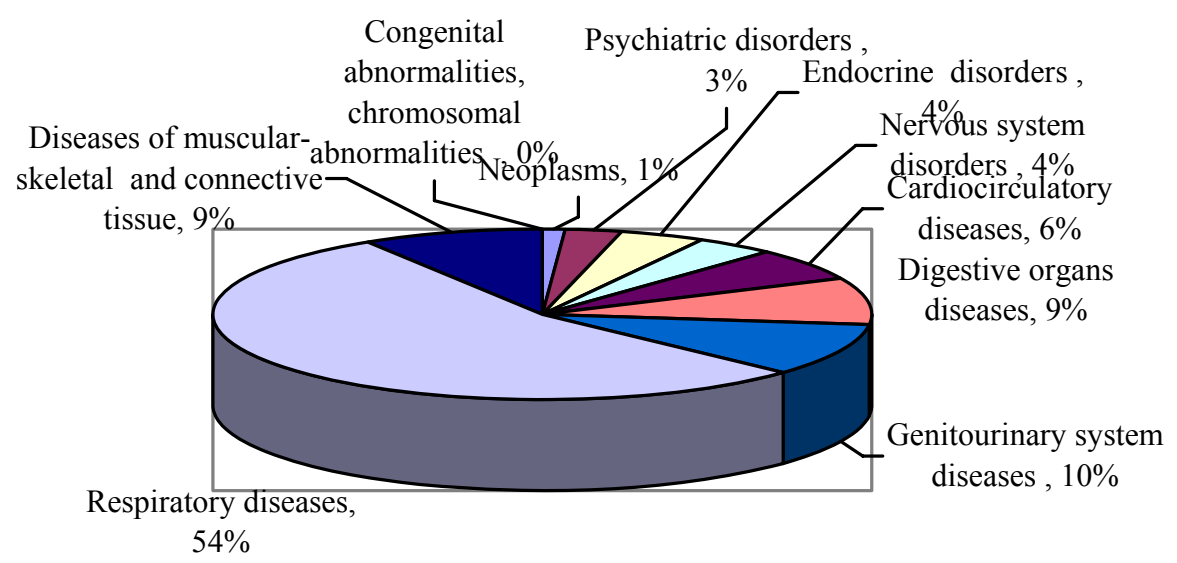

Figure 2. - Morbidity of population for main groups of diseases (registered patients with emergence diseases per 100000 persons) in mining settlements of P. Osipenko district: Briakan, Kherpuchi, Otlongi and other)

TABLE 1. - CONTENTS OF SOME CHEMICAL ELEMENTS IN BIOLOGICAL MATERIAL (CHILDREN'S HAIR, MCG/G, IN DIFFERENT REGIONS OF RUSSIA) (GUDKOV, BAGRYANTSEV, KUZNETSOV, ET AL, 2005) AND BRIAKAN MINING SETTLEMENT IN KHABAROVKIY KRAI (AVERAGE IN 2011-2012)

\begin{tabular}{|c|c|c|c|c|c|c|}
\hline Regions & $\mathrm{Pb}$ & $\mathrm{Cu}$ & $\mathrm{Cd}$ & $\mathrm{Zn}$ & $\mathrm{Cr}$ & $\mathrm{Hg}$ \\
\hline Briakan & 5.87 & 16.28 & 0.41 & 199.95 & 3.29 & 1.37 \\
\hline settlement & 3.58 & 11.3 & 0.19 & 132.8 & & \\
\hline $\begin{array}{l}\text { Non-Black soil } \\
\text { zone }\end{array}$ & 7.24 & 10.1 & 0.38 & 131.5 & & \\
\hline $\begin{array}{l}\text { Central Black earth } \\
\text { zone } \\
\text { Trans-Caucasian } \\
\text { region } \\
\text { (mountainous) }\end{array}$ & 4.81 & 10.5 & 0.35 & 155.7 & & \\
\hline
\end{tabular}

To ensure environmental and social security of mercury contaminated wastes, technogenic mercury contamination it is proposed: to develop the Program of environmental safety for the regions of gold mining, including reclamation of the natural environment and recreation. We consider it necessary to include improving of the regulatory and legal framework, binding the subsoil users to certify the technogenic mining units (waste) by categories of their production and economic value that will allow to put them in the category of secondary resources, defining the areas of their economic use. One of the most important activities is the health promotion of the mining settlement population to prevent environmentally caused diseases (using effective sorbents of natural origin such as: "Polyphepan", "Litovit", "Feokarpin", "Lamiforen"). The service of preservation of industrial past for the future generations memory in the mining regions of FEFD should be created.

\section{CONCLUSIONS}

A high level of pollution in the area of research, unfavourable ecological situation, changing of natural landscape habit and structure contribute to environmentally caused diseases. As the anthropogenic press on the environment and changes in natural systems increase, the role of environmental management grows. The activities aimed to reduce the negative impact of mercury pollution on the environment and the health of the mining settlement population were developed.

\section{ACKNOWLEDGEMENTS}

The research work was supported by the Russian Science Foundation.

\section{REFERENCES}

[1] V.I . Vernadsky. Living matter, Moscow: Nauka (1978), 357p.

[2] B.P. Kolesnikov, L.V Motorina. Methods of study of biogeocenoses in technogene landscapes, Moscow, Nauka (1963), 150 p.

[3] A.I. Gorovaya, L.F. Bobyr, V.M. Digurko et al. Methodical aspects of mutagenic background and genetic hazard for man and biota caused by mutagenic ecological factors.Cytology and Genetics (1996)vol.30, no.6, pp.78-86

[4] L.T. Krupskaya, A.M. Ivlev, B.G. Saksin et al. Assessment of environment systems transformation under the impact of mining production in the Southern Far East. Khabarovsk, KhSTU ( 2001), 193 p.

[5] L.T. Krupskaya, A.M. Derbentseva, T.Yu. Bitkina et al. Bioindication methods as the element of mining-ecological monitoring of mining objects impact zones in the Southern Russian Far East. Ecological Systems and Equipoment/ (2005), No 11pp.6-9.

[6] N.K. Rastanina, L.T. Krupskaya. On the role of ecological factors in studying health of the population of miners' townships in the South of Far East. Ecology and Industry of Russia (2008) No 12, pp.56-57

[7] L.T. Krupskaya, V.P. Zvereva, A.V. Leonenko. Impact of technogenic systems on the environment in Priamurye and Primorye. Siberean Ecological Journal.(2013), vol.20, No 2pp.278-284. 